
Not for reproduction, distribution or commercial use.

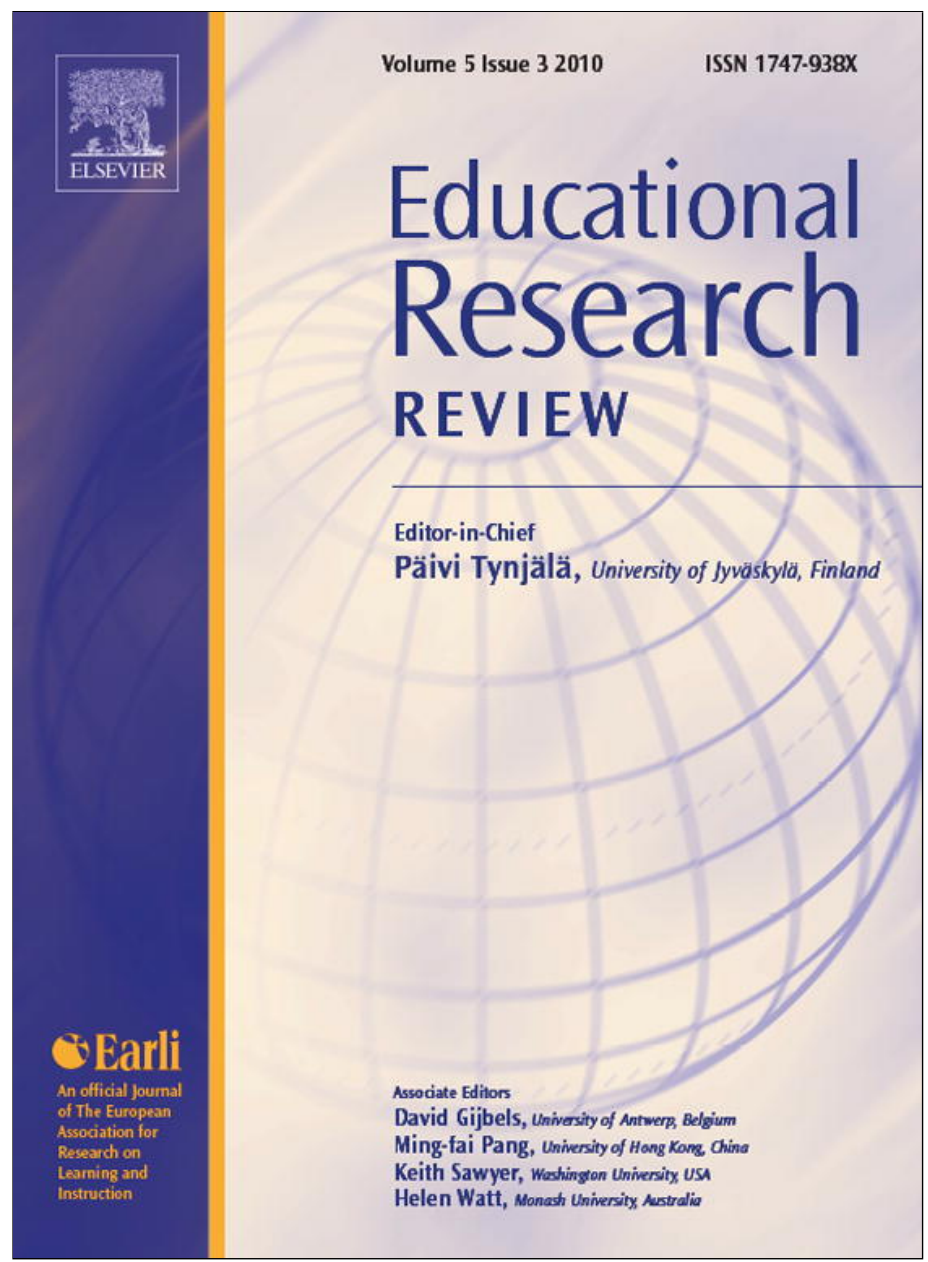

This article appeared in a journal published by Elsevier. The attached copy is furnished to the author for internal non-commercial research and education use, including for instruction at the authors institution and sharing with colleagues.

Other uses, including reproduction and distribution, or selling or licensing copies, or posting to personal, institutional or third party websites are prohibited.

In most cases authors are permitted to post their version of the article (e.g. in Word or Tex form) to their personal website or institutional repository. Authors requiring further information regarding Elsevier's archiving and manuscript policies are encouraged to visit:

http://www.elsevier.com/copyright 
Review

\title{
Using student-centred learning environments to stimulate deep approaches to learning: Factors encouraging or discouraging their effectiveness
}

\author{
Marlies Baeten*,1,2, Eva Kyndt, Katrien Struyven, Filip Dochy \\ Centre for Research on Professional Development, Corporate Training and Lifelong Learning, Katholieke Universiteit Leuven, Belgium
}

\section{A R T I C L E I N F O}

\section{Article history:}

Received 8 February 2010

Received in revised form 10 June 2010

Accepted 14 June 2010

\section{Keywords:}

Approaches to learning

Student-centred learning environment

Higher education

\begin{abstract}
A B S T R A C T
This review outlines encouraging and discouraging factors in stimulating the adoption of deep approaches to learning in student-centred learning environments. Both encouraging and discouraging factors can be situated in the context of the learning environment, in students' perceptions of that context and in characteristics of the students themselves. Results show that students in different disciplines differ in the approach to learning they adopt, with students in human sciences in general showing the deepest approach. Moreover, teachers play a role; if they are involved and oriented towards students and changing their conceptions, students are inclined to use a deep approach. With regard to perceived contextual factors, results indicate that students who are satisfied with the course quality (e.g. appropriateness of workload/assessment, teaching, and clarity of goals) employ a deep approach. Concerning the student factors, older students and students whose personality is characterised by openness to experience, extraversion, conscientiousness, agreeableness and emotional stability use a deeper approach. In addition, if students are intrinsically motivated, feel self-confident and self-efficacious and prefer teaching methods that support learning and understanding, a deep approach will be more frequently adopted.
\end{abstract}

(c) 2010 Elsevier Ltd. All rights reserved.

\section{Contents}

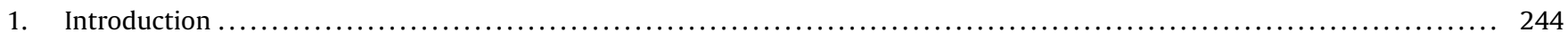

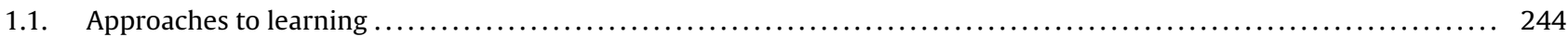

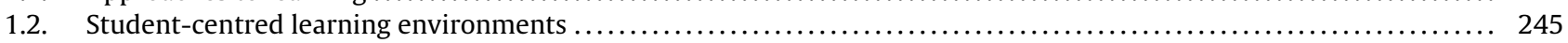

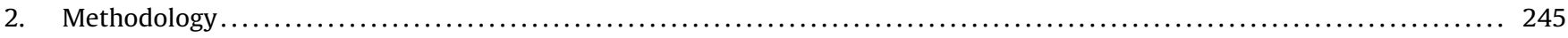

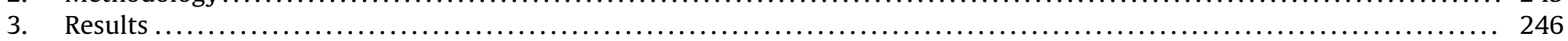

3.1. Which factors encourage or discourage the adoption of deep approaches to learning in a student-centred

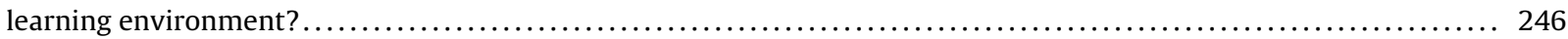

3.2. How do these encouraging and discouraging factors influence students' approaches to learning? ................. 246

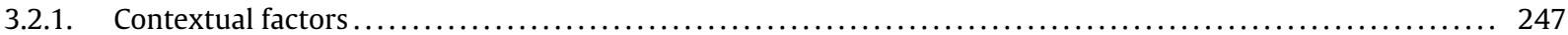

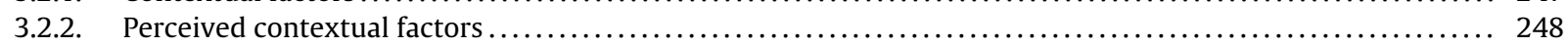

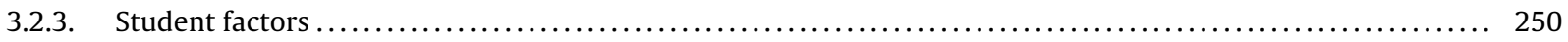

\footnotetext{
* Corresponding author at: Centre for Research on Professional Development, Corporate Training and Lifelong Learning (K.U. Leuven), Dekenstraat 2 Box 3772, 3000 Leuven, Belgium. Tel.: +32 163260 25; fax: +32 16325736.

E-mail addresses: Marlies.Baeten@ped.kuleuven.be (M. Baeten), Eva.Kyndt@ped.kuleuven.be (E. Kyndt),

Katrien.Struyven@ped.kuleuven.be (K. Struyven), Filip.Dochy@ped.kuleuven.be (F. Dochy).

1 The first two authors made equal contribution in this work and are both equally considered as first author.

2 The contribution of Marlies Baeten was supported by an Aspirant FWO grant from the Fund for Scientific Research Flanders (FWO Vlaanderen).
} 


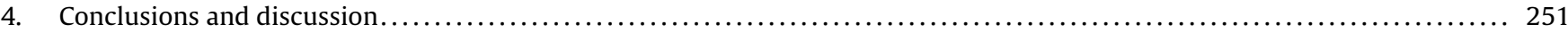

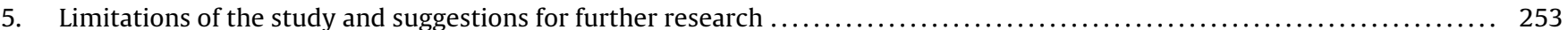

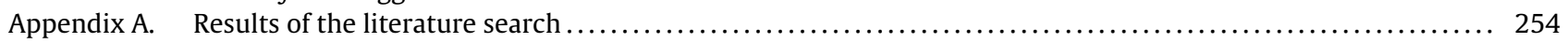

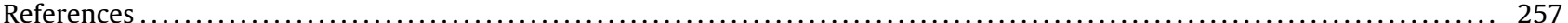

\section{Introduction}

Over the past decades, a large amount of research has been conducted on students' learning in higher education. One way to describe students' learning is by means of their 'approaches to learning', which is the focus of the current review. An approach to learning embeds the intention of the student when starting a task and the learning processes and strategies used to carry out a task (Biggs, 2001; Entwistle, 1991, 1997; Marton \& Säljö, 1997). Numerous attempts have been made to optimise students' approaches to learning towards deep, meaningful learning by means of implementing student-centred teaching methods (e.g. Struyven, Dochy, Janssens, \& Gielen, 2006; Wilson \& Fowler, 2005). However, these efforts have not always been successful. Inducing a deep approach to learning seems to be quite difficult (Marton \& Säljö, 1997). Therefore, this review focuses on factors that may encourage or discourage the adoption of a deep approach to learning in student-centred learning environments.

\subsection{Approaches to learning}

With Marton and Säljö being pioneers in the 1970s (Marton, 1976; Säljö, 1975), the concept of approaches to learning has been a firmly established concept in the educational research literature for several decades now. Originally, Marton (1976) and Säljö (1975) used a phenomenographic research approach to reveal differences between students in how they approached a specific task. While some students made use of deep learning processes which were associated with an intention to understand, others used surface learning processes in order to reproduce the learning materials. This combination of intention and related processes was called an 'approach to learning'.

Based on the results of the phenomenographic research of Marton and Säljö, a new research tradition arose, i.e. quantifying students' approaches to learning by means of self-report questionnaires. As a consequence, several inventories were developed in the subsequent years based on this approaches to learning perspective (Lonka, Olkinuora, \& Mäkinen, 2004). In the current review, we focus on two of the most frequently used questionnaires to measure students' approaches to learning in higher education (Entwistle \& McCune, 2004; Leung, Ginns, \& Kember, 2008; Richardson, 2004), i.e. the Approaches to Studying Inventory (ASI) (Entwistle \& Ramsden, 1983) and the Study Process Questionnaire (SPQ) (Biggs, 1987).

The ASI (Entwistle \& Ramsden, 1983) distinguishes four sets of related intentions, motives and processes of learning and studying, which are referred to as four orientations to studying: meaning, reproducing, achieving and non-academic orientation. Students with a meaning orientation are motivated by an interest in the learning contents and an intention to understand. Therefore, they use strategies as relating ideas, using evidence and comprehension learning. Oppositely, students with a reproducing orientation show an extrinsic motivation and a fear of failure, which is accompanied with rote memorisation and a narrow-syllabus-bound attitude. Furthermore, students with an achieving orientation are stimulated by a need for achievement. These students are aware of the study requirements and try to accomplish them by using organised study methods. The latter group of students with a non-academic orientation, which is sometimes referred to as an apathetic approach (Tait \& Entwistle, 1996), put across low levels of motivation, negative attitudes towards studying and disorganised study methods (Entwistle \& McCune, 2004; Entwistle \& Tait, 1990).

Similarly, the SPQ (Biggs, 1987) discriminates three factors or 'approaches to learning' consisting of a motive and a related strategy component: a deep, surface and achieving approach. The motive of students with a deep approach is an intrinsic interest and appropriate engagement in the task, which is accompanied with seeking for meaning as learning strategy. In contrast, students with a surface approach are motivated by a fear of failure and a desire to keep out of trouble with as little effort as possible. As a consequence, their learning strategies are limited to selective memorisation. The achieving approach refers to students making an effective use of space and time (=strategy) in order to maximise grades (=motive) (Biggs, Kember, \& Leung, 2001). Whereas the first two approaches describe ways in which students handle a learning task, the achieving (or strategic) approach indicates how students organise their learning (e.g. when, where, how long they learn) (Biggs et al., 2001; Lonka et al., 2004).

The conceptualisation of learning (meaning/deep versus reproducing/surface), which is grounded in the original conceptualisation of Marton and Säljö, is similar in both questionnaires (Entwistle \& McCune, 2004) and central to the current review. Moreover, a third aspect of studying is described in both questionnaires, i.e. the achieving or strategic approach. However, recent research on the SPQ has shown that approaches to learning are best described through the use of two factors, namely a deep and surface approach, without the need for a separate strategic approach scale (Zeegers, 2002). It has been suggested that the strategic approach should be more correctly seen as a component of the deep approach (Kember \& Leung, 1998; Zeegers, 2002, 2004). On the other hand, in a recent version of the ASI (Entwistle, McCune, \& Hounsell, 2002), the strategic approach is still present by means of two scales: organised studying (including time management) and effort management (including concentration) (Entwistle \& McCune, 2004). Throughout the years several research studies have been conducted on both questionnaires resulting in adapted versions of the original ASI and SPQ, e.g. Revised Approaches to Studying Inven- 
tory (RASI) (Entwistle \& Tait, 1994), Approaches and Study Skill Inventory for Students (ASSIST) (Tait, Entwistle, \& McCune, 1998), Approaches to Learning and Studying Inventory (ALSI) (Entwistle \& McCune, 2004), and Revised Two Factor Study Process Questionnaire (R-SPQ-2F) (Biggs et al., 2001).

As research on students' approaches to learning evolved, interest arose in factors explaining those approaches, such as the teaching methods, since approaches to learning are not considered to be a stable psychological trait (Nijhuis, Segers, \& Gijselaers, 2005; Struyven et al., 2006). On the contrary, they depend crucially on the context within which a task is being experienced (Entwistle, 1991; Entwistle \& McCune, 2004). As a consequence, a student can adopt one approach in a certain context and another approach in another context, depending on the characteristics of that context and the learner's interpretation thereof (Biggs, 2001).

\subsection{Student-centred learning environments}

The past decennia, a wide range of new teaching methods came up due to the influence of the constructivist learning theory, which defined learning as an "active process in which learners are active sense makers who seek to build coherent and organised knowledge" (Mayer, 2004, p. 14). This constructivist learning theory acted as a source for the development of student-centred approaches (Hannafin, Hill, \& Land, 1997), which were described by Cannon and Newble (2000, pp. 16-17) as "ways of thinking about teaching and learning that emphasise student responsibility and activity in learning rather than content or what the teachers are doing". Accordingly, several teaching methods were developed that indeed emphasised students' behavioural activity during learning (Mayer, 2004), e.g. student-activating teaching methods (Struyven et al., 2006), problem-based learning (Dochy, Segers, Van den Bossche, \& Gijbels, 2003), powerful learning environments (De Corte, 2000), minimal guidance approach (Kirschner, Sweller, \& Clark, 2006), discovery learning (Mayer, 2004), open-ended learning environments (Hannafin et al., 1997), collaborative/cooperative learning (Slavin, 1995), project-based learning (Dekeyser \& Baert, 1999), and case-based learning (Ellis, Marcus, \& Taylor, 2005). Characteristics of these student-centred teaching methods are: (1) an activity and independence of the student, (2) a coaching role of the teacher, and (3) knowledge which is regarded as a tool instead of an aim (Dochy, Segers, Gijbels, \& Van den Bossche, 2002). These teaching methods that emphasise students' activity are often presented as the opposite of traditional lectures where the teacher provides information that is passively received by the students (Prince, 2004).

While there is a lot of confusion about what student-centred learning actually is (Lea, Stephenson, \& Troy, 2003) and while it can take many different teaching forms in practice as is illustrated above, one recurring aim of these teaching methods is fostering deep learning and understanding (Hannafin et al., 1997; Lea et al., 2003; Mayer, 2004), which can be expressed by a deep approach to learning. In the previous decade, both ASI and SPQ and their adapted versions were used to investigate the effects of student-centred learning environments on approaches to learning, in particular on the deep approach. However, those studies did not show univocal results. Researchers investigating this topic have given possible explanations for their results, hereby offering suggestions for which factors can encourage or discourage the adoption of a deep approach in student-centred learning environments. Therefore, the first goal of this review is to identify those suggested encouraging and discouraging factors. After the identification of these factors, a second literature search will be done to investigate the nature of the relationship between the suggested encouraging and discouraging factors and students' approaches to learning. In this second part of the review, research studies that have empirically investigated the relationship between the suggested factor and students' approaches to learning will be selected, independent of the learning environment in which the study took place. As a consequence, the research questions addressed in this review study are:

1. Which factors encourage or discourage the adoption of deep approaches to learning in a student-centred learning environment?

2. How do these encouraging and discouraging factors influence students' approaches to learning?

\section{Methodology}

To answer the first research question, studies that investigated the influence of student-centred learning environments on students' approaches to learning were explored in order to identify encouraging and discouraging factors. Search terms were "approach(es) to learning" and "learning approach(es)" combined with key words that referred to, or were examples of, student-centred learning environments: "student-cent(e)red learning”, “student-cent(e)red teaching”, "active learning”, “constructivist learning”, “student-activating”, “problem-based learning”, “powerful learning environment”, "minimal guidance", “discovery learning”, “open-ended learning environment”, “collaborative learning”, “cooperative learning", "project-based learning", and "case-based learning”. Only studies in which the teaching methods made use of the core of student-centred teaching, i.e. emphasising student responsibility and activity in learning (Cannon \& Newble, 2000) and a coaching role of the teacher (Dochy et al., 2002), were retrieved. Factors encouraging or discouraging a deep approach to learning were searched for in the conclusion, discussion, summary and limitations part of the retrieved articles.

In order to answer the second research question, the relationships between the encouraging and discouraging factors and students' approaches to learning were investigated in-depth by searching literature concerning these relationships. 
Therefore, the search terms "approach(es) to learning" and "learning approach(es)" were combined with the specific variables/factors (see below, e.g. "workload", "assessment”, etc.) which were found as an answer to the first research question.

This literature search was conducted by means of the electronic search platform LibriSource+, which made it possible to search several electronic databases simultaneously. Four databases were included in the search: Eric (CSA + USDE), PsycInfo (OvidSP), Web of Science and FRANCIS. The literature for the narrative analysis (Dochy, Segers, \& Buehl, 1999) was selected, based on several criteria for inclusion, by reading the abstracts of the studies: (1) the studies had to address higher education students' approaches to learning consisting of the intention of the student when starting a task and the learning strategies used to carry out a task; (2) the studies had to measure approaches to learning by means of questionnaires based on ASI and SPQ; (3) the retrieved studies had to be published after 2000 for the first research question and after 1990 for the second research question; (4) studies had to concern the learning approaches of students without (learning) disabilities; and (5) studies regarding the relationship between encouraging and discouraging factors on the one hand, and approaches to learning on the other hand, had to indicate clear relationships between these variables, so that the significant effect (or explained variance) could be attributed to a clearly defined variable. As a result, 25 articles were retrieved regarding the first research question. Based on these 25 articles encouraging and discouraging factors were identified. To answer the second research question, 93 articles were selected. Those 93 articles investigated the nature of the relationship between these encouraging and discouraging factors and approaches to learning.

\section{Results}

\subsection{Which factors encourage or discourage the adoption of deep approaches to learning in a student-centred learning environment?}

The results of the studies addressing the effects of student-centred learning environments on students' approaches to learning were not univocal. Several studies using pre- and post-test measures of approaches to learning, before and after experiencing student-centred teaching methods, confirmed the hypothesis that these teaching methods deepened students' learning approaches (Gordon \& Debus, 2002; Sivan, Wong Leung, Woon, \& Kember, 2000; Tiwari et al., 2006; Waters \& Johnston, 2004), whereas other studies showed a significant increase in the use of surface approaches (Baeten, Dochy, \& Struyven, 2008; Gijbels, Coertjens, Vanthournout, Struyf, \& Van Petegem, 2009; Gijbels \& Dochy, 2006; Gijbels, Segers, \& Struyf, 2008; Papinczak, Young, Groves, \& Haynes, 2008; Struyven et al., 2006) or surface learning strategies (Nijhuis et al., 2005; Segers, Nijhuis, \& Gijselaers, 2006), and a decrease in the use of deep approaches (Groves, 2005; Papinczak et al., 2008; Reid, Duvall, \& Evans, 2005; Struyven et al., 2006) or deep learning strategies (Nijhuis et al., 2005; Segers et al., 2006). Balasooriya, Hughes, and Toohey (2009) and Balasooriya, Toohey, and Hughes (2009) found that while some students adopted deeper approaches, a notable proportion of the students adopted more surface approaches or showed minimal changes in their approaches. Chung and Chow (2004), Herington and Weaven (2008), McParland, Noble, and Livingston (2004), and Wong and Lam (2007) did not find any significant difference between pre- and post-test measures of students' deep and surface approaches in a student-centred learning environment.

A number of studies compared two or more learning environments that differed in the degree of student-centredness. While some studies emphasised the surplus value of student-centred teaching methods for fostering deep approaches (Richardson, Dawson, Sadlo, Jenkins, \& McInnes, 2007; Tetik, Gurpinar, \& Bat, 2009; Wilson \& Fowler, 2005), other studies found the opposite, i.e. more surface approaches in student-centred learning environments (Nijhuis et al., 2005; Segers et al., 2006). McParland et al. (2004) on the other hand did not find any significant difference in students' approaches when comparing problem-based learning to traditional lectures. Finally, research using only post-test measures of approaches to learning at the end of a problem-based learning experience (Gijbels, van de Watering, Dochy, \& Van den Bossche, 2005; Schultz \& Christensen, 2004) showed that students had higher scores for the deep approach than for the surface approach to learning.

These mixed findings make clear that influencing students' approaches towards deep learning by means of implementing student-centred learning environments is a complex process. Numerous other factors that encourage or discourage the adoption of a deep approach may be of influence. In the 25 retrieved articles, the authors tried to explain their results by indicating encouraging and discouraging factors, based on literature, previous empiric research, interviews with students and their own ideas. The overview of these factors is presented in Fig. 1. For the clarity of the figure, references are left out and are included in Appendix A. As is made clear in Fig. 1, encouraging and discouraging factors are situated in the context and students' perceptions of that context, but also in characteristics of the students themselves.

\subsection{How do these encouraging and discouraging factors influence students' approaches to learning?}

To investigate the nature of the relationships between encouraging and discouraging factors (see Fig. 1) and students' approaches to learning, 93 articles were retrieved from our literature search. In Appendix A, references of these articles are grouped by factor. Next, the results concerning contextual factors, perceived contextual factors, and student factors are presented separately. 


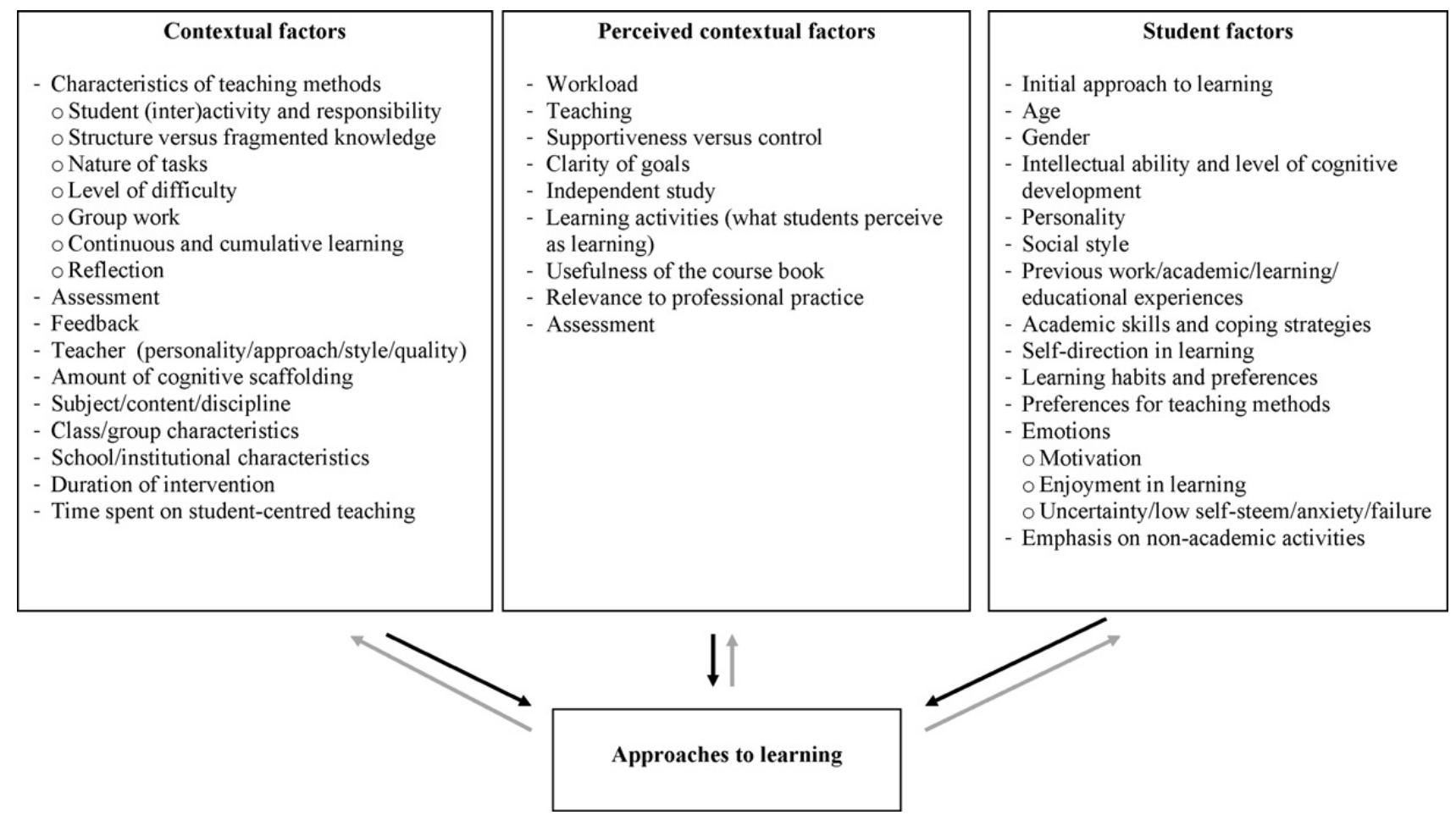

Fig. 1. Overview of encouraging and discouraging factors.

\subsubsection{Contextual factors}

Different encouraging and discouraging factors were identified in the context in which the student learns. However, only the influence of five of these contextual factors (assessment, feedback, teacher, interactivity, and discipline) on students' approaches to learning was empirically investigated in the studies retrieved in our literature search.

Concerning assessment, three studies were retrieved measuring approaches to learning at the start and the end of a course in which students were assessed by means of formative group assignments (Gijbels \& Dochy, 2006), portfolio assessment (Baeten et al., 2008; Struyven et al., 2006), multiple choice examination, case-based evaluation and peer-assessment (Struyven et al., 2006). These assessment modes - with the exception of the multiple choice examination - suited the innovative assessment culture (Birenbaum, 1996) that intended to enhance students' deep approaches to learning (Dochy \& Moerkerke, 1997; Gielen, Dochy, \& Dierick, 2003). However, a significant increase in terms of surface approaches to learning was found in these studies. Also the multiple choice examination did not increase students' adoption of deep approaches. Instead, the surface approach to learning increased significantly, however, only when used in combination with studentactivating teaching methods. When used in a lecture-based setting, no significant differences were found between surface approaches to learning at the start and the end of the course (Struyven et al., 2006).

Furthermore, two studies used one single measure of approaches to learning to investigate the effects of different assessment modes on students' learning. In this way, Smith and Miller (2005) asked students how they would approach their learning if expecting a multiple choice examination or an essay, but they did not find any significant effect of assessment type on students' learning. Kwok and Ma (1999) studied students' approaches in a collaborative assessment setting, in which both teachers and students participated in the assessment process. In particular, they investigated whether a difference could be found between students who received feedback through an internet-based group support system and students who received this feedback face to face. It proved to be that the deep approach of the former group was significantly higher than that of the latter group.

The effects of different kinds of feedback on students' approaches to learning were also examined in the study of Gijbels et al. (2009). They executed a two-year study in which they manipulated the nature and amount of feedback in two cohorts. While cohort 1 received only oral teacher- and peer-feedback on their presentations of two authentic group assignments, cohort 2 received written peer-feedback which was used in a formative way. As a consequence, cohort 2 could revise their assignments afterwards in view of their summative assessment. However, receiving additional feedback in cohort 2 did not explain deep and surface approaches to learning over and above their initial deep and surface approaches and student characteristics.

Besides assessment and feedback, the teacher is mentioned as contextual factor too. Factor and cluster analysis on the relationship between teachers' approaches to teaching and students' approaches to learning indicated that students of teachers who reported adopting approaches to teaching that were more oriented towards students and to changing students' conceptions, reported adopting significantly deeper approaches to learning. Conversely, in the classes where teachers 
described their approach to teaching as having a focus on what they do and on transmitting knowledge, students were more likely to report the adoption of a surface approach to learning (Trigwell, Prosser, \& Waterhouse, 1999). Also the amount of involvement and presence of the teacher seems to matter, as was indicated by Garrison and Cleveland-Innes (2005). They investigated students' approaches to learning in four courses that differed in the amount of teacher involvement in online conferencing, and they concluded that teacher involvement contributed to the adoption of deep approaches to learning. Nevertheless, they acknowledged the importance of the content and task demands which should require processes such as critical discourse, reflection and thought in order to attain a deeper approach to learning.

As a part of the teaching approach, Booth and James (2001) focused on the interactivity in lectures. They investigated whether students' deep approaches improved in an interactive lecture where the teacher posed questions to the students at appropriate points in time. After having thought about these questions in silence, students discussed the solution together with a partner. Afterwards one student was selected by the teacher to answer. Despite the increased interactivity in the lecture, students' deep approaches to learning did not increase.

Not only didactic elements in the course but also the content and subject of the course, or broader the discipline or area of study, influence students' approaches to learning. Several studies were in favour of human sciences, in particular arts, social sciences, psychology, language/literature, health, politics and philosophy. As such, Kember, Leung, and McNaught (2008) concluded that the nature of the typical teaching and learning environment in the arts and social sciences was more conducive to students cultivating a deep approach than that in science and economics. The results of Lawless and Richardson (2002) were analogous. Students taking courses in arts subjects scored significantly higher on deep approach than students taking courses in science subjects, even when controlled for workload. When comparing psychology and business students, Smith and Miller (2005) found a significantly higher deep approach in the group of psychology students. With regard to language and health disciplines, Yin (1999) found a significantly higher deep approach in these disciplines compared to construction and engineering disciplines. A final study indicating the surplus value of human sciences in stimulating the adoption of a deep approach is the one of Eley (1992), who showed that students studying English literature, politics and philosophy scored higher on the deep approach than students in (bio)chemistry, microbiology, mathematics, statistics and accounting and business courses. Valk and Marandi (2005) on the other hand found that students from the faculties of biology, geography, physics and chemistry had the deepest approaches to learning compared to students from faculties of math, informatics, social sciences, philosophy, education, economics and law.

Although the direction of the differences in the abovementioned studies is not univocal, it can be concluded that discipline seems to matter in the adoption of deep approaches to learning. Nevertheless, some studies did not find any significant differences between disciplines, e.g. Edmunds and Richardson (2009) could not differentiate between sociology, biosciences, and business students' approaches to learning, and Watkins and Regmi (1990) came to the same conclusions for humanities, science and management students.

\subsubsection{Perceived contextual factors}

It has often been stated that it is not the learning environment in itself that influences learning, but the way students perceive it (Entwistle, 1991; Zeegers, 2001). Students will always interpret instructional interventions and this interpretation triggers the effects of the learning environment (Elen \& Lowyck, 2000). As a consequence, a considerable amount of research has concentrated on students' perceptions. Workload, teaching, supportiveness, clarity of goals, usefulness of course book, independent study, relevance to professional practice and assessment have been empirically investigated in relation to students' approaches to learning. The results of these studies are discussed next.

The workload of a learning environment is an important factor which has an influence on approaches to learning. Because of the difficulty of determining the true objective workload, research has mostly measured students' perceptions of the workload. Earlier research sometimes used 'hours of work or study' as a measurement of workload, but Kember (2004) stated that this was not a good measurement of workload because time is merely a component of what shapes the perceived workload of a student. Research results on the relationship between perceived workload and approaches to learning are quite univocal, except for the study of Karagiannopoulou and Christodoulides (2005) who did not find any significant relationship. Besides this study, many researchers have showed that an excessive perceived or inappropriate workload is positively associated at a significant level with a surface approach (Crawford, Gordon, Nicholas, \& Prosser, 1998; Diseth, 2007a, 2007b; Diseth, Pallesen, Hovland, \& Larsen, 2006; Entwistle \& Tait, 1990; Kember, 2004; Kember \& Leung, 1998; Kember, Ng, Pomfret, Tse, \& Wong, 1996; Lawless \& Richardson, 2002; Lizzio, Wilson, \& Simons, 2002; Wilson, Lizzio, \& Ramsden, 1997) and significantly negative with a deep approach to learning (Cope \& Staehr, 2005; Crawford et al., 1998; Diseth, 2007a, 2007b; Diseth et al., 2006; Kember et al., 1996; Wilson et al., 1997). Svirko and Mellanby (2008) did not investigate perceived workload in general, but focused on information load and came to similar results, i.e. students who perceived an overload of information scored higher on the surface and lower on the deep approach. Kember (2004) offered a possible explanation for these findings concerning perceived workload, in that he stated that students resort to short cuts and undesirable study approaches, i.e. the surface approach, to cope with the perceived excessive demands.

Next to workload, the way in which students perceive teaching is also of influence on the way they learn. If they perceive the teaching as 'good', students are more inclined towards using a deep approach and less towards using a surface approach (Crawford et al., 1998; Diseth et al., 2006; Entwistle \& Tait, 1990; Lawless \& Richardson, 2002; Trigwell \& Prosser, 1991a; Wilson et al., 1997). Diseth (2007b) found a similar but indirect effect of perceived teaching quality (presentation, 
integration and lecturer characteristics) on students' approaches via the perceived effect of the teaching (challenge, overall value and stimulation of interest). While the former studies related good teaching to a deep approach, Pimparyon, Roff, McAleer, Poonchai, and Pemba (2000) found positive correlations between perceptions of teaching and both deep and surface approach. In contrast to general teaching quality, Leung, Lu, Chen, and Lu (2008) studied four qualitatively different teaching approaches, i.e. the transferring, shaping, travelling and growing teaching approach. While the former two are teacher-centred and focus on a one-way process of transferring knowledge to or shaping of students, the latter two are student-centred and consider the student with his own experiences as a fellow traveller whose learning process is facilitated by the teacher. Perceived teacher-centred teaching approaches were found to be mainly positively related to a surface approach, while perceived student-centred teaching approaches were found to be mainly positively correlated to a deep approach. In addition, the surface strategy was found to be related to the traveling teaching approach, while the deep strategy was found to be related to the shaping teaching approach. Valk and Marandi (2005) investigated students' perceptions of concrete teaching behaviours and found that answering students' questions, giving feedback, structuring the course, providing materials and illustrating lectures were significantly positively correlated with a deep approach, whereas a surface approach was significantly negatively related to the teaching strategy of structuring the course. Surprisingly, no correlation was found between a deep approach and teaching activities that encouraged students' active participation, e.g. the teacher gave group tasks and projects to students. Concerning the perceived supportiveness of the context, Eley (1992) indicated that perceived teaching support, i.e. giving general support and encouragement for a student's learning, was related to a deep approach. Furthermore, the degree to which the teacher was perceived to have made goals and standards clear throughout the course was positively related to a deep approach and negatively to a surface approach (Crawford et al., 1998; Eley, 1992; Lawless \& Richardson, 2002; Nijhuis et al., 2005; Trigwell \& Prosser, 1991a; Wilson et al., 1997). The same relationships were found concerning perceived independent study (Crawford et al., 1998; Eley, 1992; Lawless \& Richardson, 2002; Trigwell \& Prosser, 1991a; Valk \& Marandi, 2005; Wilson et al., 1997). Also the usefulness of the course book (e.g. more straightforward and clear cut, and less conceptual, less holistic and less cross-disciplinary) is an influencing factor in stimulating students towards deep learning (Nijhuis et al., 2005). In addition, the more students perceived the course as relevant to their professional practice, the stronger their deep approach to learning was (Entwistle \& Tait, 1990).

While there is a large amount of studies investigating the relationship between students' approaches to learning and their learning outcomes (e.g. Minbashian, Huon, \& Bird, 2004; Trigwell \& Prosser, 1991b), fewer studies addressed the reverse relationship, i.e. the pre-assessment or backwash effect of assessment on learning, according to which the student anticipates the perceived assessment requirements and as a consequence changes his approach to learning to meet these requirements (Gielen et al., 2003). Therefore, perceptions of the assessment modes are considered to be important to take into account in research on approaches to learning. Students who perceive the assessment demands on a deep level, as assessing higher levels of cognitive processing, are found to employ deep approaches (Scouller, 1998) or deep learning strategies (Segers et al., 2006), whereas students who perceive the assessment as assessing lower, knowledge-based levels of intellectual processing or aiming at rote recall, tend to employ surface approaches (Scouller, 1998; Trigwell \& Prosser, 1991a) or surface strategies (Segers et al., 2006). In Segers et al. (2006), the relationship between perceptions of assessment and approaches to learning occurred irrespective of the assessment mode that was used (knowledge reproduction questions versus case-based assessment, i.e. mainly knowledge application questions), indicating that students who intended to adopt a deep or surface learning strategy perceived the assessment demands accordingly and, as a result, employed a related learning strategy. Scouller (1998), on the other hand, found different perceptions of the assessment modes, with the assignment essay being perceived as assessing higher levels of intellectual processing compared to a multiple choice examination. Segers, Martens, and Van den Bossche (2008) found that it was primarily the perceptions of the case-based assessment demands on a deep level that influenced students' learning approaches: they had a positive effect on the use of deep approaches and a negative effect on the employment of surface learning approaches. Gijbels et al. (2008) found that only changes in the perceptions of assessment towards less surface levels were significantly related to changes in approaches to learning, but surprisingly to a more surface approach.

Besides looking at the perceived level of the assessment demands (deep versus surface), previous research also focused on the perceived appropriateness and other characteristics of assessment. Concerning the appropriateness of assessment, research results showed a negative relationship between perceived inappropriate assessment and a deep approach. The reverse relationship was found for the surface approach (Crawford et al., 1998; Lawless \& Richardson, 2002; Trigwell \& Prosser, 1991a; Wilson et al., 1997). Gulikers, Kester, Kirschner, and Bastiaens (2008) proved that students who perceived the assessment as being more authentic and more resembling their future professional practice, employed deeper learning than students who perceived the assessment as being less authentic. Furthermore, the study of Segers, Gijbels, and Thurlings (2008) showed through correlational analyses that students who perceived the portfolio assessment as stimulating their learning and being motivating and who reported to use the feedback they received on the portfolio assessment were more inclined to use a deep approach. The reverse pattern was found with the surface approach. Moreover, students who were more negative about the quantity, timing and quality of the feedback, showed a stronger surface approach.

While the abovementioned studies focused on specific elements of the learning environment, other studies incorporated general measures of the overall quality of the course. Results of these studies all point in the same direction, with perceptions of overall course quality being positively related to a deep approach and negatively to a surface approach (Diseth, 2007a; Diseth, Pallesen, Brunborg, \& Larsen, 2010; Richardson et al., 2007). 


\subsubsection{Student factors}

Although research on the effects of student-centred learning environments tends to focus on the learning approaches of the whole group of students, a lot of encouraging and discouraging student factors were identified as an answer to research question 1 , indicating the student-dependent nature of approaches to learning. Many of these student factors have been empirically investigated in relation to approaches to learning. The variables initial approach to learning, age, gender, intellectual ability and level of cognitive development, personality, previous experiences, learning habits, preferences for teaching methods, motivation, and uncertainty/low self-esteem/anxiety/failure are discussed below.

First of all, the learning approach which students adopt in a learning environment, whether it is student-centred or not, is influenced by their initial approach to learning at the moment of entering the learning environment, i.e. students' deep and surface approaches in a learning environment are significantly positively predicted by respectively their initial deep and surface approaches (Crawford et al., 1998; Fox, McManus, \& Winder, 2001; McParland et al., 2004). Gijbels et al. (2008) investigated the relationship between the initial approach to learning and the change in approaches to learning in a studentcentred learning environment and found that students' lack of change in terms of a deep learning approach was significantly negatively influenced by their initial deep approach. Accordingly, students' change in surface learning approaches was significantly negatively influenced by their initial surface approach. So, the stronger the initial deep or surface approach of students, the less they change their approach. Wilson and Fowler (2005) compared the deep approaches to learning of deep and surface learners in a conventional teacher-centred course and an action learning-based course (project work, learning groups). Their results showed that deep learners remained relatively consistent in their deep approach to learning across the two learning environments, indicating that these students were not influenced by the action learning course. Surface learners, on the other hand, reported a significantly greater use of deep learning strategies in the action learning course, but there was no corresponding increase in their motives for deep learning. These findings appear to be in contrast with the finding that students with a preference for deep approaches were more likely to recognize the learning potential of constructivist teaching strategies than were students with surface learning preferences, who tend to focus on the transmissive aspects of teaching and the reproductive aspects of learning (Campbell et al., 2001).

Students' approaches to learning are usually measured by means of separate variables, namely the deep and surface approach. In practice, however, students combine features of both approaches which form their learning profiles (Vanthournout, Donche, Gijbels, \& Van Petegem, 2009). Vanthournout et al. (2009) distinguished several subgroups of students with the same learning profile and investigated whether these subgroups evolved differently in their approaches in the same student-activating learning environment. Their results showed that the approaches to learning for the different learning profiles converged, i.e. students with a high ambivalent (=high deep/high surface) and deep approach-profile significantly decreased in their deep approach while the deep approach of students with a surface approach or fallen angels-profile (=moderate/low deep and surface) significantly increased. No significant changes in deep approach were found for students with a moderate ambivalent-profile (=moderate deep and high surface). A similar converging pattern was found for the surface approach. Leung, Mok, and Wong (2008) also distinguished several subgroups of students based on their learning profile. In a course, without specific intervention of student-centred teaching methods, they found no significant changes in deep approach for the three subgroups (high surface/low deep, intermediate, low surface/high deep). Concerning the surface approach, a significant increase was found in the low surface/high deep subgroup. In the intermediate group a significant increase was found in only one of the two study programs.

Over the years, age and gender have become two important demographic variables in the research field of approaches to learning. Studies that have taken the variable age into account mainly showed that age was positively related to a deep approach and negatively to a surface approach (Chamorro-Premuzic \& Furnham, 2009; Christie, Cree, Hounsell, McCune, \& Tett, 2006; Diseth, 2007b; Duff, 1999; Edmunds \& Richardson, 2009; Furnham, Christopher, Garwood, \& Martin, 2007; Gijbels et al., 2005; Groves, 2005; McParland et al., 2004; Richardson, 1995; Richardson, Morgan, \& Woodley, 1999; SadlerSmith, 1996; Valk \& Marandi, 2005; Zeegers, 2001, 2004; Zhang, 2003). However, some studies did not find a significant relationship between age and learning approach (Duff, Boyle, Dunleavy, \& Ferguson, 2004; Mattick, Dennis, \& Bligh, 2004; Papinczak et al., 2008; Tiwari et al., 2006), but they are rather exceptions.

Concerning gender, several research studies have confirmed a relation with approach to learning. Unfortunately, the nature of the relationships differs among the studies. Some studies found that males scored higher on the surface approach than females (Berberoglu \& Hei, 2003; Gijbels et al., 2005; Mattick et al., 2004; Tetik et al., 2009) but other studies found the reverse (Cantwell \& Grayson, 2002; Duff, 2002; Duff et al., 2004; Furnham et al., 2007; Sadler-Smith, 1996). Concerning the deep approach, females obtained higher scores for the deep approach than males (Cantwell \& Grayson, 2002; Hayes \& Richardson, 1995; Tetik et al., 2009). However, Tural Dincer and Akdeniz (2008) found this effect only in the first year; in the second, third and fourth year of study this effect disappeared. Berberoglu and Hei (2003) and Sadler-Smith (1996) on the other hand found higher scores of males than females on the deep approach. The inconclusiveness on this issue is even stronger since numerous studies did not find any significant relationship between gender and approach to learning (ChamorroPremuzic \& Furnham, 2009; Dickie, 1994; Diseth, 2007b; Donnon \& Hecker, 2008; Edmunds \& Richardson, 2009; Papinczak et al., 2008; Phan, 2007; Sobral, 2001; Watkins \& Regmi, 1990; Wilson, Smart, \& Watson, 1996; Zeegers, 2001, 2004).

In our literature search, three studies were retrieved concerning the relationship between intellectual ability and approaches to learning but they did not show comparable results. While Chamorro-Premuzic and Furnham (2008) found a significant positive correlation between a deep approach to learning and a student's intelligence quotient, this relationship was not confirmed by Diseth (2002) and Furnham, Swami, Arteche, and Chamorro-Premuzic (2008). Fluid intelligence, i.e. 
abstract reasoning, was also found to be significantly positively correlated with a deep approach in the study of ChamorroPremuzic and Furnham (2008) but not in the study of Furnham et al. (2008). In addition, Diseth (2002) indicated that the scores on a vocabulary test of intelligence were negatively correlated with the surface approach. Concerning level of cognitive development, Zhang and Watkins (2001) showed that thinking dualistically was associated with adopting more surface approaches, while thinking from multiple perspectives and using relativistic terms was associated with a stronger deep motivation. The highest level of cognitive development, i.e. making a commitment to what you value, was significantly positively related to using a deep approach.

Besides intellectual ability, personality is another rather stable student factor that influences students' approaches to learning. We retrieved nine studies concerning this topic (Arteche, Chamorro-Premuzic, Ackerman, \& Furnham, 2009; Chamorro-Premuzic, Furnham, \& Lewis, 2007; Chamorro-Premuzic \& Furnham, 2008, 2009; Diseth, 2003; Duff et al., 2004; Furnham et al., 2008; Swanberg \& Martinsen, 2010; Zhang, 2003). Main findings of the correlational analyses in these studies showed that openness to experience (e.g. being imaginative, artistically sensitive, and intellectually curious) was significantly positively related to a deep approach and significantly negatively to a surface approach. Similar patterns of relationships were found regarding extraversion (e.g. being sociable, cheerful and active), conscientiousness (e.g. being responsible, organised, and hard-working), and agreeableness (e.g. being compassionate, empathic and trustworthy), but the reverse relationships were found with regard to neuroticism (e.g. being emotionally unstable, anxious, and pessimistic).

Since students do not enter a learning environment like 'empty vessels' but bring own experiences with them, these previous experiences may influence students' approaches to learning. In particular, Beckwith (1991) found that prior knowledge about a course was significantly negatively correlated with a surface strategy, while no significant relationship was found with the deep approach. Gulikers et al. (2008) investigated whether a difference in the amount of practical experience (freshman versus senior) resulted in the adoption of different approaches to learning, but no significant differences were found. Concerning learning habits, Entwistle and Tait (1990) found that the time spent on independent studying, understanding notes and using textbooks was related to a meaning orientation.

The fact that student-centred learning environments do not always succeed in stimulating the use of deep approaches to learning might also be explained by their preferences for particular teaching methods. Research (Byrne, Flood, and Willis, 2004; Entwistle \& Tait, 1990; Papinczak, 2009) showed that a preference for teaching methods that supported understanding (e.g. lecturers who show what they think or comment on students' ideas) was significantly positively correlated with a deep approach and deep learners, whereas a preference for teaching methods that focused on transmitting information or promoting rote learning was significantly positively correlated with a surface (-apathetic) approach and surface-apathetic learners. Similar findings were found by Entwistle and Tait (1993) for successful students who passed the examination. Preferences for features of the learning environment that facilitated learning (i.e. preferences for challenging lectures, open questions in exams, discussions in tutorials, and courses which allow choice) were positively related to a meaning orientation, while surface preferences (i.e. lectures which give good notes, exams linked to lectures, tutorials reinforcing lectures, and courses with defined reading) were positively related to a reproducing orientation. Chamorro-Premuzic et al. (2007) investigated students' preferences for several interactive teaching modalities such as laboratory classes, small-group tutorials, clinical teaching and discussion groups, and several non-interactive teaching modalities like standard lectures and independent study. The results described a deep approach being significantly positively related, and a surface approach being significantly negatively related to preferences for interactive teaching methods. Kember et al. (2008) investigated the approaches to learning of students in their current study and in their most disliked course. They found that students' deep approaches were more prevalent in their current study than in their most disliked course, but the reverse pattern was observed for the surface approaches. In other words, the less preferred course was associated with a more surface approach to learning.

Since motivation and approaches to learning have often been found to be related, it may be possible that students do not reach a deep approach in a student-centred learning environment because they lack the motivation to attain that high quality level of learning (Sambell, McDowell, \& Brown, 1997). Results concerning the interrelationship of approaches and motivation showed that a deep approach was mainly associated with intrinsic (goal) orientation (Entwistle \& Tait, 1990, 1993; Entwistle et al., 2002; Harris, 2004; Thomas \& Gadbois, 2007), autonomous motivation as defined by Deci and Ryan (2000) as an experience of enacting with a sense of volition and choice (Baeten, Struyven, \& Dochy, 2009), motive for success (Diseth \& Martinsen, 2003), motivation to study (Wilson, 2009), and mastery-approach goals (Cano \& Berbén, 2009). A surface approach on the other hand was generally found to be associated with an extrinsic (goal) orientation (Entwistle et al., 2002; Harris, 2004), controlled motivation as defined by Deci and Ryan (2000) as a feeling pressured to do something (Baeten et al., 2009), fear of failure (Entwistle \& Tait, 1993), a motive to avoid failure (Diseth \& Martinsen, 2003) and performance-avoidance goals (Cano \& Berbén, 2009).

As is indicated above, both fear of failure and a motivation to avoid failure are related to the use of surface approaches to learning. By contrast, if students are more self-confident and have higher self-efficacy, they are usually inclined towards the use of a deep approach and less towards the use of a surface approach (Cassidy \& Eachus, 2000; Duff, 2004; Harris, 2004; Papinczak, 2009; Rodriguez, 2009; Thomas \& Gadbois, 2007).

\section{Conclusions and discussion}

Although student-centred learning environments were expected to stimulate students towards the use of deeper approaches to learning, empirical research in higher education did not show consistent findings. These inconsistent findings 
gave rise to the current literature review on encouraging and discouraging factors related to the use of deep approaches to learning. First, both encouraging and discouraging factors were identified within empirical research on the influence of student-centred learning environments on students' approaches to learning (research question 1). Next, the relationships between those factors and students' approaches to learning were investigated in-depth by exploring literature (research question 2), taking into account our criteria for inclusion.

Results of research question 1 show that both encouraging and discouraging factors can be situated in the context in which the student learns, in the student's perception of that context, and in characteristics of the student himself. While several encouraging and discouraging factors have a mainly univocal influence on students' approaches to learning, the relationship with some other variables is less clear. Next, the main findings to research question 2 will be overviewed.

Concerning the context, innovative assessment - which is often used in combination with student-centred learning environments - may affect students' learning, though in an undesirable direction, i.e. resulting in the adoption of more surface approaches to learning (Baeten et al., 2008; Gijbels \& Dochy, 2006; Struyven et al., 2006). This may be explained by the fact that being successful in terms of assessment does not always require a deep approach to learning. While students' deep approaches often result in qualitatively better learning outcomes (Minbashian et al., 2004; Trigwell \& Prosser, 1991a, 1991b), the use of deep approaches is not always reflected in higher quantitative learning outcomes (Byrne et al., 2004; Gijbels et al., 2005; Kember, Jamieson, Pomfret, \& Wong, 1995). Besides innovative assessment, the teacher seems to play a role in the approaches students take to go about the learning materials. If teachers are more oriented towards students and changing their conceptions (Trigwell et al., 1999) and are more involved (Garrison \& Cleveland-Innes, 2005), students are more inclined to use deep approaches. Furthermore, students in different disciplines use different approaches to learning. Most studies addressing a discipline effect are in favour of the human sciences, in particular arts, social sciences, psychology, language/literature, health, politics and philosophy, in which students score in general higher on the deep approach compared to the disciplines of science, (bio)chemistry, microbiology, construction and engineering, mathematics, statistics, economics, business and accounting (e.g. Eley, 1992; Kember et al., 2008). However, it can be questioned whether disciplines cultivate certain approaches to learning in students or whether it is the student with a certain learning approach who is attracted by a specific discipline. Moreover, the items in most questionnaires were designed with education and social science students in mind. As a consequence, the deep items might not fit other disciplines equally well, and so the effects of discipline might be attributed in part to the items not being equally valid in describing learning processes in different disciplines. Also the duration of the intervention is mentioned by numerous authors as an encouraging or discouraging factor (e.g. Baeten et al., 2008; Balasooriya, Hughes et al., 2009; Gijbels et al., 2008). As it seems difficult to encourage a deep approach, an intervention during a short period of time may not be sufficient to encourage a deep approach. It might take longer for students to change from a surface to deep approach.

Since the research studies retrieved in order to answer research question 1 mainly investigated the effects of studentcentred learning environments on the whole group of students, they looked primarily at the context-dependent nature of approaches to learning, often without paying attention to particular subgroups of students. This is an important lack because several student factors may encourage or discourage the adoption of deep approaches to learning directly or indirectly through students' perceptions of the context.

With regard to perceived contextual factors - which can differ considerably from the intentions of the curriculum designer or the expectations of the teacher (Argyris \& Schön, 1978) - it has been shown that in order to attain deep approaches to learning students should be satisfied with the overall course quality (Diseth, 2007a; Diseth et al., 2010; Richardson et al., 2007) or specific features of the course/learning environment, i.e. appropriateness of the workload (e.g. Cope \& Staehr, 2005; Diseth et al., 2006), appropriateness of the amount of information (Svirko \& Mellanby, 2008), quality of the teaching (e.g. Crawford et al., 1998; Lawless \& Richardson, 2002), supportiveness of the teacher (Eley, 1992), clarity of goals and standards (e.g. Eley, 1992; Lawless \& Richardson, 2002), usefulness of the course book (Nijhuis et al., 2005) and relevance to professional practice (Entwistle \& Tait, 1990). In addition, the more students perceive the teaching approaches as student-centred (M. Leung et al., 2008) and the more opportunities they see for independent studying (e.g. Trigwell \& Prosser, 1991a; Wilson et al., 1997), the more they incline towards a deep approach. Also students' perceptions of concrete teaching behaviours such as answering students' questions, giving feedback, structuring the course, providing materials and illustrating lectures contribute to the use of deep approaches to learning (Valk \& Marandi, 2005). Concordant with the perceptions of the teacher and teaching methods, the perceptions of the assessment modes are considered to be important. Students who perceive the assessment as appropriate (e.g. Crawford et al., 1998; Lawless \& Richardson, 2002), as assessing deep learning (e.g. Scouller, 1998; Segers et al., 2006), as authentic and resembling their future professional practice (Gulikers et al., 2008), and as stimulating their learning and being motivating (Segers, Gijbels et al., 2008), employ more deep approaches.

When attempting to induce a deep approach by means of a student-centred learning environment, it is important to take these perceived contextual factors into account by maintaining an appropriate workload and information load, by providing support, clear goals, possibilities for independent studying, etc. However, in this regard new questions may arise. For instance, how many possibilities for independent studying should be provided or which amount of workload is appropriate in order to increase deep learning. Quasi-experimental research in which these factors are manipulated could answer these questions.

As to the student factors, several relationships have been found with approaches to learning. One major variable of influence on students' actual approach to learning is their initial approach (e.g. Fox et al., 2001; McParland et al., 2004). Gijbels et al. (2008) found that the stronger the initial deep or surface approach of students, the less students change their approach. However, it seems that the initial deep and surface approach cannot change equally (S. Leung et al., 2008; Wilson 
\& Fowler, 2005). In this regard, Marton and Säljö (1997) stated previously that, in general, it was easier to induce a surface than a deep approach to learning. Other studies that investigated the variability of approaches confirmed this statement and found a significant increase or no change in the use of surface approaches and a decrease in the use of deep approaches over time (Donnon \& Hecker, 2008; Duckwall, Arnold, \& Hayes, 1991; Yin, 1999). Nijhuis, Segers, and Gijselaers (2008) even indicated that students can be divided in two groups according to the variability of their learning strategies (i.e. one component of approaches to learning), namely students whose deep and surface learning strategies vary little on the one hand and much on the other hand.

Besides initial approach to learning, other student characteristics have an impact on students' learning, several of which have a clear influence such as age, personality, preferences for teaching methods, motivation, self-confidence and selfefficacy. Both age and personality are factors that cannot be manipulated. The older students are (e.g. Chamorro-Premuzic $\&$ Furnham, 2009; Christie et al., 2006) and the more their personality is characterised by openness to experience, extraversion, conscientiousness, agreeableness and emotional stability (e.g. Chamorro-Premuzic et al., 2007; Diseth, 2003), the more they use a deep approach. So, when attempting to induce a deep approach in a student-centred learning environment, it is possible that the age and the personality of the students will prohibit the adoption of a deep approach. However, these factors - in particular age - can be taken into account when designing a learning environment for a specific group of students. In contrast to age and personality, students' motivation, self-confidence and self-efficacy can be enhanced and students' teaching preferences can be changed. If a student-centred learning environment may succeed in establishing an intrinsic or autonomous motivation (Baeten et al., 2009; Entwistle et al., 2002) or a motivation to study and reach success (Diseth \& Martinsen, 2003; Wilson, 2009), students may be encouraged to adopt a deep approach. Likewise, if students feel self-confident and show a high self-efficacy in a student-centred learning environment, they will be more inclined towards the use of a deep approach. Moreover, if students prefer teaching methods that are interactive (Chamorro-Premuzic et al., 2007), support understanding (e.g. Byrne et al., 2004), or facilitate learning (Entwistle \& Tait, 1993), a deep approach will be more frequently adopted. Furthermore, gender, intellectual ability and level of cognitive development, and previous experiences seemed to matter in the way students approach their learning but less clear relationships were found.

\section{Limitations of the study and suggestions for further research}

While the use of criteria for inclusion is necessary to have a focus on the wide area of research studies on approaches to learning, those criteria create limitations too. First of all, we included only studies that measured approaches to learning as defined by the intention of the student when starting a task and the learning processes and strategies used to carry out a task (Biggs, 2001; Entwistle, 1991, 1997; Marton \& Säljö, 1997). Since this definition of approaches to learning and the related instruments of ASI (Entwistle \& Ramsden, 1983), SPQ (Biggs, 1987) and adapted versions of both are still frequently used in contemporary research (see research question 1), we preferred to use this narrow conception of approaches to learning.

Secondly, this review is based only on the quantitative research tradition on approaches to learning since this research methodology is often used to estimate the effects of student-centred learning environments on students' approaches to learning. Nevertheless, a review of qualitative research studies on approaches to learning could complement our findings.

Thirdly, throughout this review the concept of approaches to learning is used as a monolithic entity while in fact it comprises several characteristics, for example a deep approach refers to an intention to understand, an intrinsic interest in the task, relating ideas, using evidence, etc. (see Section 1.1). Therefore, it might not be clear which aspect of the deep approach is being influenced by the factors in the studies reviewed. Future research could address this issue. Similarly, as was indicated in Section 1.2, many different teaching methods are used under the banner of student-centred learning environments, and each of those will be implemented in different ways, depending on both institutional circumstances as well as the varying interpretations of the teachers. As a consequence, differences in results may be inherent to differences in implementation of student-centred learning environments. What's more, students are often not familiar with student-centred teaching methods, and therefore the influence of student-centred learning environments on the use of deep approaches could be prohibiting. Therefore, future research could look at the influence of mixed learning environments where, for example, the student-centred learning environment is supported by lectures or where a student-centred learning environment is gradually implemented. The use of a mixed learning environment could explain why Sivan et al. (2000) and Wilson and Fowler (2005) found a positive influence of a student-centred learning environment on the use of a deep approach, while other researchers did not (e.g. Nijhuis et al., 2005; Segers et al., 2006; Struyven et al., 2006). In Sivan et al. (2000) and Wilson and Fowler (2005) research, students received both lectures (teacher-centred) and student-centred teaching methods which was not the case in the other studies.

Fourthly, the review looked at relationships between single factors and approaches to learning as indicated by the model in Fig. 1. However, reality is much more complex and many factors which are interrelated might influence student learning. These simple relationships, however, might be a starting point to explore the influencing factors of students' approaches to learning and their relatedness in-depth.

Finally, in spite of the large body of literature on learning approaches, a lot of the variables in Fig. 1 have not been investigated. In this respect, it should be noticed that there might be some publication bias. These encouraging and discouraging factors might be investigated but not published if they did not show significant effects or might not be retrieved in our literature search. For instance, lack of feedback and working in groups are very often suggested as an encouraging or discouraging 
factor for inducing a deep learning approach. These two variables have been investigated in other educational research which has indicated their positive influence on learning (e.g. Hänze \& Berger, 2007; Krause, Stark, \& Mandl, 2009), but none of these studies met our criteria for inclusion. Reversely, there are several other factors which may influence students' approaches in a student-centred learning environment. However, these factors were not mentioned as encouraging or discouraging factors in the conclusion, discussion, summary and limitations part of the retrieved articles to answer research question 1 , and are therefore not included in Fig. 1, e.g. locus of control (Cassidy \& Eachus, 2000) and English language ability (Gow, Kember, \& Chow, 1991).

Despite these limitations, the current review gives a clear overview of encouraging and discouraging factors of students' approaches to learning, thereby showing the complex process of stimulating students towards the use of deep approaches to learning in student-centred learning environments. The results of this review study could serve as a basis for new studies to fill in the gaps in our knowledge about approaches to learning.

\section{Appendix A. Results of the literature search}

Encouraging/discouraging factor

Contextual factors

Student (inter)activity and responsibility

Structure versus fragmented knowledge

Nature of tasks

Level of difficulty

Group work

Continuous and cumulative learning

Reflection

Assessment

Feedback

Teacher (personality/approach/style/quality)

Amount of cognitive scaffolding

Subject/content/discipline

Class/group characteristics

School/institutional characteristics

Duration of intervention

Articles proposing factors that encourage or discourage the adoption of deep approaches in student-centred learning environments (research question 1 )

Tiwari et al. (2006) and Wilson and Fowler (2005)

Gijbels and Dochy (2006), Gijbels et al. (2009), Herington and Weaven (2008) and Struyven et al. (2006)

Gordon and Debus (2002), Tetik et al. (2009) and Waters and Johnston (2004)

Papinczak et al. (2008)

Balasooriya, Hughes et al. (2009), Herington and Weaven (2008), Struyven et al. (2006), Waters and Johnston (2004) and Wilson and Fowler (2005)

Waters and Johnston (2004)

Waters and Johnston (2004)

Groves (2005), Herington and Weaven (2008), Papinczak et al. (2008), Tetik et al. (2009) and Wong and Lam (2007)

Gijbels et al. (2009), Gijbels and Dochy (2006) and Struyven et al. (2006)

Baeten et al. (2008), Gijbels et al. (2005), Groves (2005), Herington and Weaven (2008), Struyven et al. (2006) and Tetik et al. (2009)

Papinczak et al. (2008)

Herington and Weaven (2008), Papinczak et al. (2008), Struyven et al. (2006) and Wilson and Fowler (2005)

Struyven et al. (2006) and Gijbels et al. (2005)

Struyven et al. (2006) and Wong and Lam (2007)

Baeten et al. (2008), Balasooriya, Hughes et al. (2009), Gijbels et al. (2008, 2009), Herington and Weaven (2008), McParland et al. (2004), Nijhuis et al. (2005), Reid et al. (2005) and Wilson and Fowler (2005)
Articles investigating the relationship between encouraging/discouraging factors and approaches to learning (research question 2)

Booth and James (2001)

Baeten et al. (2008), Gijbels and Dochy (2006), Kwok and Ma (1999), Smith and Miller (2005) and Struyven et al. (2006)

Gijbels et al. (2009)

Garrison and McCleveland-Innes (2005) and Trigwell et al. (1999)

Edmunds and Richardson (2009), Eley (1992), Kember et al. (2008), Lawless and Richardson (2002), Smith and Miller (2005), Valk and Marandi (2005), Watkins and Regmi (1990) and Yin (1999) 
Articles proposing factors that encourage or discourage the adoption of deep approaches in student-centred learning environments (research question 1 )
Articles investigating the relationship between encouraging/discouraging factors and approaches to learning (research question 2)

Time spent on student-centred teaching

Reid et al. (2005)

Perceived contextual factors

Workload

Baeten et al. (2008), Gijbels and Dochy (2006), Gijbels et al. (2008, 2009), Groves (2005), Herington and Weaven (2008), Nijhuis et al. (2005), Papinczak et al. (2008), Segers et al. (2006), Struyven et al. (2006) and Wong and Lam (2007)

Teaching

Struyven et al. (2006)

Papinczak et al. (2008) and Tetik et al. (2009)

Gijbels et al. (2008) and Nijhuis et al. (2005)

Clarity of the goals

Independent study

Learning activities (what students perceive as learning)

Usefulness of the course book

Relevance to professional practice

Assessment

Student factors

Initial approach to learning
Balasooriya, Hughes et al. (2009), Gijbels et al. (2008), Nijhuis et al. (2005) and Tetik et al. (2009)

Gijbels et al. (2009)

Nijhuis et al. (2005)

Balasooriya, Hughes et al. (2009)

Baeten et al. (2008), Gijbels et al. (2005),

Nijhuis et al. (2005) and Papinczak et al. (2008)
Cope and Staehr (2005), Crawford et al. (1998), Diseth (2007a, 2007b), Diseth et al. (2006), Entwistle and Tait (1990), Karagiannopoulou and Christodoulides (2005), Kember (2004), Kember and Leung (1998), Kember et al. (1996), Lawless and Richardson (2002), Lizzio et al. (2002), Svirko and Mellanby (2008) and Wilson et al. (1997)

Crawford et al. (1998), Diseth (2007b), Diseth et al. (2006), Entwistle and Tait (1990), Lawless and Richardson (2002), M. Leung et al. (2008), Pimparyon et al. (2000), Trigwell and Prosser (1991a), Valk and Marandi (2005) and Wilson et al. (1997)

Eley (1992)

Crawford et al. (1998), Eley (1992), Lawless and Richardson (2002), Nijhuis et al. (2005), Trigwell and Prosser (1991a) and Wilson et al. (1997)

Crawford et al. (1998), Eley (1992), Lawless and Richardson (2002), Trigwell and Prosser (1991a), Valk and Marandi (2005) and Wilson et al. (1997)

Nijhuis et al. (2005)

Entwistle and Tait (1990)

Crawford et al. (1998), Gijbels et al. (2008), Gulikers et al. (2008), Lawless and Richardson (2002), Scouller (1998), Segers et al. (2006), Segers, Gijbels et al. (2008), Segers, Martens et al. (2008), Trigwell and Prosser (1991a) and Wilson et al. (1997)

Crawford et al. (1998), Fox et al. (2001), Gijbels et al. (2008), S. Leung et al. (2008), McParland et al. (2004), Vanthournout et al. (2009) and Wilson and Fowler (2005)
Balasooriya, Toohey et al. (2009), Gijbels and Dochy (2006), Gijbels et al. (2008), Herington and Weaven (2008), Reid et al. (2005), Struyven et al. (2006), Wilson and Fowler (2005) and Wong and Lam (2007) 


\section{Appendix A (Continued)}

Encouraging/discouraging factor

Gender

Intellectual ability and level of cognitive development

Personality

\section{Social style}

Previous work/academic/learning/educational experience

Academic skills and coping strategies

Self-direction in learning

Learning habits and preferences
Articles proposing factors that encourage or discourage the adoption of deep approaches in student-centred learning environments (research question 1 )

Gijbels et al. (2005) and Groves (2005)

Gijbels et al. (2005) and Struyven et al. (2006)

Balasooriya, Hughes et al. (2009) and Papinczak et al. (2008)

Groves (2005) and Herington and Weaven (2008)

\section{Herington and Weaven (2008)}

Balasooriya, Hughes et al. (2009), Groves (2005), Papinczak et al. (2008), Richardson et al. (2007), Segers et al. (2006) and Struyven et al. (2006)

Balasooriya, Toohey et al. (2009) and Segers et al. (2006)

Tetik et al. (2009) and Tiwari et al. (2006)

Balasooriya, Hughes et al. (2009), Papinczak et al. (2008) and Struyven et al. (2006)
Articles investigating the relationship between encouraging/discouraging factors and approaches to learning (research question 2)

Chamorro-Premuzic and Furnham (2009), Christie et al. (2006), Diseth (2007b), Duff (1999), Duff et al. (2004) Edmunds and Richardson (2009), Furnham et al. (2007), Gijbels et al. (2005), Groves (2005), Mattick et al. (2004), McParland et al. (2004), Papinczak et al. (2008), Richardson (1995). Richardson et al. (1999), Sadler-Smith (1996), Tiwari et al. (2006), Valk and Marandi (2005), Zeegers (2001, 2004) and Zhang (2003)

Berberoglu and Hei (2003), Cantwell and Grayson (2002), Chamorro-Premuzic and Furnham (2009), Dickie (1994), Diseth (2007b), Donnon and Hecker (2008), Duff (2002), Duff et al. (2004), Edmunds and Richardson (2009), Furnham et al. (2007) Gijbels et al. (2005), Hayes and Richardson (1995). Mattick et al. (2004), Papinczak et al. (2008), Phan (2007), Sadler-Smith (1996), Sobral (2001), Tetik et al. (2009), Tural et al. (2008), Watkins and Regmi (1990), Wilson et al. (1996) and Zeegers (2001, 2004)

Chamorro-Premuzic and Furnham (2008), Diseth (2002), Furnham et al. (2008) and Zhang and Watkins (2001)

Arteche et al. (2009), Chamorro-Premuzic et al. (2007), Chamorro-Premuzic and Furnham $(2008,2009)$ Diseth (2003), Duff et al.

(2004), Furnham et al. (2008), Swanberg and Martinsen (2010) and Zhang (2003)

Beckwith (1991) and Gulikers et al. (2008)

Entwistle and Tait (1990) 


\section{Appendix A (Continued)}

Encouraging/discouraging factor
Articles proposing factors that encourage or discourage the adoption of deep approaches in student-centred learning environments (research question 1 )
Articles investigating the relationship between encouraging/discouraging factors and approaches to learning (research question 2)

Preferences for teaching methods

Balasooriya, Toohey et al. (2009)

Byrne et al. (2004),
Chamorro-Premuzic et al. (2007), Entwistle and Tait (1990, 1993), Kember et al. (2008) and Papinczak (2009)

Motivation Baeten et al. (2008), Balasooriya, Toohey et al. (2009), Herington and Weaven (2008), Papinczak et al. (2008), Struyven et al. (2006), Tetik et al. (2009), Tiwari et al. (2006) and Wong and Lam (2007)

Enjoyment in learning

Uncertainty/low self-esteem/anxiety/failure (2009), Struyven et al. (2006) and Tiwari et al. (2006)
Baeten et al. (2009), Cano and Berbén (2009), Diseth and Martinsen (2003), Harris (2004), Entwistle et al. (2002), Entwistle and Tait (1990, 1993), Thomas and Gadbois (2007) and Wilson (2009)

$-$

Cassidy and Eachus (2000), Duff (2004), Harris (2004), Papinczak (2009), Rodriguez (2009) and Thomas and Gadbois (2007)

\section{References}

Argyris, C., \& Schön, D. (1978). Organizational learning: A theory of action perspective. Reading, MA: Addison-Wesley.

Arteche, A., Chamorro-Premuzic, T., Ackerman, P., \& Furnham, A. (2009). Typical intellectual engagement as a byproduct of openness, learning approaches, and self-assessed intelligence. Educational Psychology, 29(3), 357-367.

Baeten, M., Dochy, F., \& Struyven, K. (2008). Students' approaches to learning and assessment preferences in a portfolio-based learning environment. Instructional Science, 36, 359-374.

Baeten, M., Struyven, K., \& Dochy, F. (2009). Student teachers' approaches to learning in relation to their motivation and their perceived competence. Paper presented at the conference of the International Study Association on Teachers and Teaching, Rovaniemi, Finland.

Balasooriya, C., Hughes, C., \& Toohey, S. (2009). Impact of a new integrated medicine program on students' approaches to learning. Higher Education Research and Development, 28(3), 289-302.

Balasooriya, C., Toohey, S., \& Hughes, C. (2009). The cross-over phenomenon: Unexpected patterns of change in students' approaches to learning. Studies in Higher Education, 34(7), 781-794.

Beckwith, J. (1991). Approaches to learning, their context and relationship to assessment performance. Higher Education, 22(1), 17-30.

Berberoglu, G., \& Hei, L. (2003). A comparison of university students' approaches to learning across Taiwan and Turkey. International Journal of Testing, 3(2), $173-187$.

Biggs, J. B. (1987). Study process questionnaire manual. Melbourne: Australian Council for Educational Research.

Biggs, J. B. (2001). Enhancing learning: A matter of style or approach? In R. J. Sternberg, \& L. Zhang (Eds.), Perspectives on thinking, learning, and cognitive styles (pp. 73-102). Mahwah, NJ: Lawrence Erlbaum Associates.

Biggs, J., Kember, D., \& Leung, D. Y. P. (2001). The revised two-factor study process questionnaire: R-SPQ-2F. British Journal of Educational Psychology, 71(1), $133-149$.

Birenbaum, M. (1996). Assessment 2000: Towards a pluralistic approach to assessment. In M. Birenbaum, \& F. Dochy (Eds.), Assessment of achievements, learning processes and prior knowledge (pp. 9-29). Boston: Kluwer Academic.

Booth, K., \& James, B. (2001). Interactive learning in a higher education Level 1 mechanics module. International Journal of Science Education, 23(9), 955-967.

Byrne, M., Flood, B., \& Willis, P. (2004). Using the student learning framework to explore the variation in academic performance of European business students. Journal of Further and Higher Education, 28(1), 67-78.

Campbell, J., Smith, D., Boulton-Lewis, G., Brownlee, J., Burnett, P. C., Carrington, S., et al. (2001). Students' perception of teaching and learning: The influence of students' approaches to learning and teachers' approaching to teaching. Teachers and Teaching: Theory and Practice, 7(2), $173-187$.

Cannon, R., \& Newble, D. (2000). A handbook for teachers in universities and colleges. A guide to improving teaching methods (4th ed.). London: Kogan Page.

Cano, F., \& Berbén, A. B. G. (2009). University students' achievement goals and approaches to learning in mathematics. British Journal of Educational Psychology, $79(1), 131-153$

Cantwell, R., \& Grayson, R. (2002). Individual differences among enabling students: A comparison across three enabling programmes. Journal of Further and Higher Education, 26(4), 293-306.

Cassidy, S., \& Eachus, P. (2000). Learning style, academic belief systems, self reported student proficiency and academic achievement in higher education. Educational Psychology, 22(3), 307-319.

Chamorro-Premuzic, T, \& Furnham, A. (2008). Personality, intelligence and approaches to learning as predictors of academic performance. Personality and Individual Differences, 44, 1596-1603.

Chamorro-Premuzic, T., \& Furnham, A. (2009). Mainly openness: The relationship between the Big Five personality traits and learning approaches. Learning and Individual Differences, 19, 524-529.

Chamorro-Premuzic, T., Furnham, A., \& Lewis, M. (2007). Personality and approaches to learning predict preference for different teaching methods. Learning and Individual Differences, $17,241-250$.

Christie, H., Cree, V., Hounsell, J., McCune, V., \& Tett, L. (2006). From college to university: Looking backwards, looking forwards. Research in Post-Compulsory Education, 11(3), 351-365.

Chung, J., \& Chow, S. (2004). Promoting student learning through a student-centred problem-based learning subject curriculum. Innovations in Education and Teaching International, 41(2), 157-168. 
M. Baeten et al. / Educational Research Review 5 (2010) 243-260

Cope, C., \& Staehr, L. (2005). Improving students' learning approaches through intervention in an information systems learning environment. Studies in Higher Education, 30(2), 181-197.

Crawford, K., Gordon, S., Nicholas, J., \& Prosser, M. (1998). Qualitatively different experiences of learning mathematics at university. Learning and Instruction, $8(5), 455-468$

Deci, E. L., \& Ryan, R. M. (2000). The "what" and "why" of goal pursuits: Human needs and the self-determination of behavior. Psychological Inquiry, 11(4), 227-268.

De Corte, E. (2000). Marrying theory building and the improvement of school practice: A permanent challenge for instructional psychology. Learning and Instruction, 10(3), 249-266.

Dekeyser, L., \& Baert, H. (1999). [Project-based learning: Learning and working in group] Projectonderwijs: Leren en werken in groep. Leuven: Acco.

Dickie, L. (1994). Approach to learning and assessment in physics. Quebec, Canada: John Abbott College., ISBN 0-921017-18-9.

Diseth, A. (2002). The relationship between intelligence, approaches to learning and academic achievement. Scandinavian Journal of Educational Research, 46(2), 219-230.

Diseth, A. (2003). Personality and approaches to learning as predictors of academic achievement. European Journal of Personality, 17, 143-155

Diseth, A. (2007a). Approaches to learning, course experience and examination grade among undergraduate psychology students: Testing of mediator effects and construct validity. Studies in Higher Education, 32(3), 373-388.

Diseth, A. (2007b). Students' evaluation of teaching, approaches to learning, and academic achievement. Scandinavian Journal of Educational Research, 51(2), 185-204.

Diseth, A., \& Martinsen, O. (2003). Approaches to learning, cognitive style, and motives as predictors of academic achievement. Educational Psychology, 23(2), 195-207.

Diseth, A., Pallesen, S., Brunborg, G., \& Larsen, S. (2010). Academic achievement among first semester undergraduate psychology students: The role of course experience, effort, motives and learning strategies. Higher Education, 59, 335-352.

Diseth, A., Pallesen, S., Hovland, A., \& Larsen, S. (2006). Course experiences, approaches to learning and academic achievement. Education and Training, $48(2-3), 156-169$.

Dochy, F., \& Moerkerke, G. (1997). Assessment as a major influence on learning and instruction. International Journal of Educational Research, 27(5), 415-432.

Dochy, F., Segers, M., \& Buehl, M. (1999). The relation between assessment practices and outcomes of studies: The case of research on prior knowledge. Review of Educational Research, 69(2), 145-186.

Dochy, F., Segers, M., Gijbels, D., \& Van den Bossche, P. (2002). [Student-centred education \& problem-based education. Significance, background and effects] Studentgericht onderwijs \& probleemgestuurd onderwijs. Betekenisachtergronden en effecten. Utrecht: Lemma.

Dochy, F., Segers, M., Van den Bossche, P., \& Gijbels, D. (2003). Effects of problem-based learning: A meta-analysis. Learning and Instruction, 13(5), 533-568.

Donnon, T., \& Hecker, K. (2008). A model of approaches to learning and academic achievement of students from an inquiry based bachelor of health sciences program. Canadian Journal of Higher Education, 38(1), 1-19.

Duckwall, J., Arnold, L., \& Hayes, J. (1991). Approaches to learning by undergraduate students: A longitudinal study. Research in Higher Education, 32(1), $1-13$.

Duff, A. (1999). Access policy and approaches to learning. Accounting Education, 8(2), 99-110.

Duff, A. (2002). Approaches to learning: Factor invariance across gender. Personality and Individual Differences, 33, 997-1010.

Duff, A. (2004). The Revised Approaches to Studying Inventory (RASI) and its use in management education. Active Learning in Higher Education, 5, 56-72.

Duff, A., Boyle, E., Dunleavy, K., \& Ferguson, J. (2004). The relationship between personality, approach to learning and academic performance. Personality and Individual Differences, 36, 1907-1920.

Edmunds, R., \& Richardson, J. (2009). Conceptions of learning, approaches to studying and personal development in UK higher education. British Journal of Educational Psychology, 79, 295-309.

Elen, J., \& Lowyck, J. (2000). Instructional metacognitive knowledge: A qualitative study on conceptions of freshman about instruction. Journal of Curriculum Studies, 32(3), 421-444.

Eley, M. (1992). Differential adoption of study approaches within individual students. Higher Education, 23(3), 231-254.

Ellis, R., Marcus, G., \& Taylor, R. (2005). Learning through inquiry: Student difficulties with online course-based material. Journal of Computer Assisted Learning, 21, 239-252.

Entwistle, N. J. (1991). Approaches to learning and perceptions of the learning environment. Introduction to the special issue. Higher Education, 22, 201-204.

Entwistle, N. J. (1997). Contrasting perspectives on learning. In F. Marton, D. Hounsell, \& N. Entwistle (Eds.), The experience of learning. Implications for teaching and studying in higher education (2nd ed., pp. 3-22). Edinburgh: Scottish Academic Press.

Entwistle, N., \& McCune, V. (2004). The conceptual bases of study strategy inventories. Educational Psychology Review, 16(4), $315-345$.

Entwistle, N.J., McCune, V., \& Hounsell, D. (2002). Occassional report 1: Approaches to studying and perceptions of university teaching-learning environments: concepts, measures and preliminary findings. ETL Project, Universities of Edinburgh, Coventry and Durham. Available from: http://www.ed.ac.uk/etl.

Entwistle, N. J., \& Ramsden, P. (1983). Understanding student learning. London: Croom Helm.

Entwistle, N. J., \& Tait, H. (1990). Approaches to learning, evaluations of teaching, and preferences for contrasting academic environments. Higher Education, $19,169-194$.

Entwistle, N., \& Tait, H. (1993). Approaches to studying and preferences for teaching in higher education. Paper presented at the annual meeting of the American Educational Research Association, Atlanta.

Entwistle, N. J., \& Tait, H. (1994). The revised approaches to studying inventory. Edinburgh: University of Edinburgh, Centre for Research into Learning and Instruction.

Fox, R., McManus, I., \& Winder, B. (2001). The shortened Study Process Questionnaire: An investigation of its structure and longitudinal stability using confirmatory factor analysis. British Journal of Educational Psychology, 71, 511-530.

Furnham, A., Christopher, A. N., Garwood, J., \& Martin, G. N. (2007). Approaches to learning and the acquisition of general knowledge. Personality and Individual Differences, 43, 1563-1571.

Furnham, A., Swami, V., Arteche, A., \& Chamorro-Premuzic, T. (2008). Cognitive ability, learning approaches and personality correlates of general knowledge. Educational Psychology, 28(4), 427-437.

Garrison, D., \& Cleveland-Innes, M. (2005). Facilitating cognitive presence in online learning: Interaction is not enough. The American Journal of Distance Education, 19(3), 133-148.

Gielen, S., Dochy, F., \& Dierick, S. (2003). Evaluating the consequential validity of new modes of assessment: The influence of assessment on learning including pre-, post-and true assessment effects. In M. Segers, F. Dochy, \& E. Cascallar (Eds.), Optimising new modes of assessment: In search of qualities and standards (pp. 37-54). Netherland: Kluwer Academic Publishers.

Gijbels, D., Coertjens, L., Vanthournout, G., Struyf, E., \& Van Petegem, P. (2009). Changing students' approaches to learning: A two-year study within a university teacher training course. Educational Studies, 35(5), 503-513.

Gijbels, D., \& Dochy, F. (2006). Students' assessment preferences and approaches to learning: Can formative assessment make a difference? Educational Studies, 32(4), 399-409.

Gijbels, D., Segers, M., \& Struyf, E. (2008). Constructivist learning environments and the (im)possibility to change students' perceptions of assessment demands and approaches to learning. Instructional Science, 36(5-6), 431-443.

Gijbels, D., van de Watering, G., Dochy, F., \& Van den Bossche, P. (2005). The relationship between students' approaches to learning and the assessment of learning outcomes. European Journal of Psychology of Education, 20(4), 327-341.

Gordon, C., \& Debus, R. (2002). Developing deep learning approaches and personal teaching efficacy within a preservice teacher education context. British Journal of Educational Psychology, 72(4), 483-511. 
Gow, L., Kember, D., \& Chow, R. (1991). The effects of English language ability on approaches to learning. RELC Journal, 22(1), 49-68.

Groves, M. (2005). Problem-based learning and learning approach: Is there a relationship? Advances in Health Sciences Education, $10,315-326$.

Gulikers, J., Kester, L., Kirschner, P. A., \& Bastiaens, T. J. (2008). The effect of practical experience on perceptions of assessment authenticity, study approach, and learning outcomes. Learning and Instruction, 18(2), 172-186.

Hannafin, M., Hill, J., \& Land, S. (1997). Student-centered learning and interactive multimedia: Status, issues, and implications. Contemporary Education, $68(2), 94-99$.

Hänze, M., \& Berger, R. (2007). Cooperative learning, motivational effects, and student characteristics: An experimental study comparing cooperative learning and direct instruction in 12 th grade physics classes. Learning and Instruction, 17, 29-41.

Harris, C. (2004). Understanding the role of epistemological beliefs in post-graduate studies: Motivation and conceptions of learning in first-year law students. Doctoral thesis. University of Texas at Austin.

Hayes, K., \& Richardson, J. T. E. (1995). Gender, subject and context as determinants of approaches to studying in higher education. Studies in Higher Education, 20(2), 215-222.

Herington, C., \& Weaven, S. (2008). Action research and reflection on student approaches to learning in large first year university classes. The Australian Educational Researcher, 35(3), 111-134.

Karagiannopoulou, E., \& Christodoulides, P. (2005). The impact of Greek university students' perceptions of their learning environment on approaches to studying and academic outcomes. International Journal of Educational Research, 43, 329-350.

Kember, D. (2004). Interpreting student workload and the factors which shape students' perceptions of their workload. Studies in Higher Education, 29(2), 165-184

Kember, D., Jamieson, Q. W., Pomfret, M., \& Wong, E. (1995). Learning approaches, study time and academic performance. Higher Education, $29,329-343$.

Kember, D., \& Leung, D. (1998). The dimensionality of approaches to learning: An investigation with confirmatory factor analysis on the structure of the SPQ and LPQ. British Journal of Educational Psychology, 68, 395-407.

Kember, D., Leung, D. Y. P., \& McNaught, C. (2008). A workshop activity to demonstrate that approaches to learning are influenced by the teaching and learning environment. Active Learning in Higher Education, 9, 43-56.

Kember, D., Ng, S., Pomfret, M., Tse, H., \& Wong, E. T. T. (1996). An examination of the interrelationships between workload, study time, learning approaches and academic outcomes. Studies in Higher Education, 21(3), 347-360.

Kirschner, P., Sweller, J., \& Clark, R. (2006). Why minimal guidance during instruction does not work: An analysis of the failure of constructivist, discovery, problem-based, experiential, and inquiry-based teaching. Educational Psychologist, 41(2), 75-86.

Krause, U.-M., Stark, R., \& Mandl, H. (2009). Effects of cooperative learning and feedback on e-learning in statistics. Learning and Instruction, 19(2), 158-170.

Kwok, R., \& Ma, J. (1999). Use of a group support system for collaborative assessment. Computers and Education, 32, 109-125.

Lawless, C., \& Richardson, J. (2002). Approaches to studying and perceptions of academic quality in distance education. Higher Education, 44, $257-282$.

Lea, S., Stephenson, D., \& Troy, J. (2003). Higher education students' attitudes to student-centred learning: Beyond 'educational boulimia'? Studies in Higher Education, 28(3), 321-334.

Leung, D., Ginns, P., \& Kember, D. (2008). Examining the cultural specificity of approaches to learning in Universities in Hong Kong and Sydney. Journal of Cross-Cultural Psychology, 39, 251-266.

Leung, M., Lu, X., Chen, D., \& Lu, M. (2008). Impacts of teaching approaches on learning approaches of construction engineering students: A comparative study between Hong Kong and Mainland China. Journal of Engineering Education, 135-145.

Leung, S., Mok, E., \& Wong, D. (2008). The impact of assessment methods on the learning of nursing students. Nurse Education Today, $28,711-719$.

Lizzio, A., Wilson, K., \& Simons, R. (2002). University students' perceptions of the learning environment and academic outcomes: Implications for theory and practice. Studies in Higher Education, 27, 27-52.

Lonka, K., Olkinuora, E., \& Mäkinen, J. (2004). Aspects and prospects of measuring studying and learning in higher education. Educational Psychology Review, 16(4), 301-323.

Marton, F. (1976). On non-verbatim learning. II. The erosion of a task induced learning algorithm. Scandinavian Journal of Psychology, 17, 41-48.

Marton, F., \& Säljö, R. (1997). Approaches to learning. In F. Marton, D. Hounsell, \& N. Entwistle (Eds.), The experience of learning. Implications for teaching and studying in higher education (2nd ed., pp. 39-58). Edinburgh: Scottish Academic Press.

Mattick, K., Dennis, I., \& Bligh, J. (2004). Approaches to learning and studying in medical students: Validation of a revised inventory and its relation to student characteristics and performance. Medical Education, 38, 535-543.

Mayer, R. (2004). Should there be a three-strikes rule against pure discovery learning? The case for guided methods of instruction. American Psychologist, 59(1), 14-19.

McParland, M., Noble, L. M., \& Livingston, G. (2004). The effectiveness of problem-based learning compared to traditional teaching in undergraduate psychiatry. Medical Education, 38, 859-867.

Minbashian, A., Huon, G. F., \& Bird, K. D. (2004). Approaches to studying and academic performance in short-essay exams. Higher Education, 47, 161-176.

Nijhuis, J., Segers, M., \& Gijselaers, W. (2005). Influence of redesigning a learning environment on student perceptions and learning strategies. Learning Environments Research, 8, 67-93.

Nijhuis, J., Segers, M., \& Gijselaers, W. (2008). The extent of variability in learning strategies and students' perceptions of the learning environment. Learning and Instruction, 18, 121-134.

Papinczak, T. (2009). Are deep strategic learners better suited to PBL? A preliminary study. Advances in Health Science Education, 14, 337-353.

Papinczak, T., Young, L., Groves, M., \& Haynes, M. (2008). Effects of a metacognitive intervention on students' approaches to learning and self-efficacy in a first year medical course. Advances in Health Sciences Education, 13, 213-232.

Phan, H. P. (2007). An Examination of reflective thinking, learning approaches, and self-efficacy beliefs at the university of the South-Pacific: A path analysis approach. Educational Psychology, 27(6), 789-806.

Pimparyon, P., Roff, S., McAleer, S., Poonchai, B., \& Pemba, S. (2000). Educational environment, student approaches to learning and academic achievement in a Thai nursing school. Medical Teacher, 22(4), 359-364.

Prince, M. (2004). Does active learning work? A review of the research. Journal of Engineering Education, 93(3), $223-231$.

Reid, W., Duvall, E., \& Evans, P. (2005). Can we influence medical students' approaches to learning? Medical Teacher, 27(5), $401-407$.

Richardson, J. (1995). Cultural specificity of approaches to studying in higher education: A comparative investigation using the approaches to studying inventory. Educational and Psychological Measurement, 55, 300-308.

Richardson, J. (2004). Methodological issues in questionnaire-based research on student learning in higher education. Educational Psychology Review, 16(4), 347-358.

Richardson, J., Dawson, L., Sadlo, G., Jenkins, V., \& McInnes, J. (2007). Perceived academic quality and approaches to studying in the health professions. Medical Teacher, 29, 108-116.

Richardson, J. T. E., Morgan, A., \& Woodley, A. (1999). Approaches to studying in distance education. Higher Education, 37, 23-55.

Rodriguez, C. (2009). The impact of academic self-concept, expectations and the choice of learning strategy on academic achievement: The case of business students. Higher Education Research and Development, 28(5), 523-539.

Sadler-Smith, E. (1996). Approaches to studying: Age, gender and academic performance. Educational Studies, 22(3), $367-379$.

Säljö, R. (1975). Qualitative differences in learning as a function of the learner's conception of a task. Gothenburg: Acta Universitatis Gothoburgensis.

Sambell, K., McDowell, L., \& Brown, S. (1997). 'But is it fair?': An exploratory study of student perceptions of the consequential validity of assessment. Studies in Educational Evaluation, 23(4), 349-371.

Schultz, N., \& Christensen, H. (2004). Seven-step problem-based learning in an interaction design course. European Journal of Engineering Education, 29(4), $533-541$. 
Scouller, K. (1998). The influence of assessment method on students' learning approaches: Multiple choice question examination versus assignment essay. Higher Education, 35, 453-472.

Segers, M., Gijbels, D., \& Thurlings, M. (2008). The relationship between students' perceptions of portfolio assessment practice and their approaches to learning. Educational Studies, 34(1), 35-44.

Segers, M., Martens, R., \& Van den Bossche, P. (2008). Understanding how a case-based assessment instrument influences student teachers' learning approaches. Teaching and Teacher Education, 24(7), 1751-1764.

Segers, M., Nijhuis, J., \& Gijselaers, W. (2006). Redesigning a learning and assessment environment: The influence on students' perceptions of assessment demands and their learning strategies. Studies in Educational Evaluation, 32, 223-242.

Sivan, A., Wong Leung, R., Woon, C., \& Kember, D. (2000). An implementation of active learning and its effect on the quality of student learning. Innovations in Education and Training International, 34(4), 381-389.

Slavin, R. E. (1995). Cooperative learning: Theory, research, and practice (2nd ed.). Englewood Cliffs, NJ: Prentice Hall.

Smith, S. N., \& Miller, R. J. (2005). Learning approaches: Examination type, discipline of study, and gender. Educational Psychology, $25(1)$, 43-53.

Sobral, D. (2001). Medical students' reflection in learning in relation to approaches to study and academic achievement. Medical Teacher, $23(5), 508-513$.

Struyven, K., Dochy, F., Janssens, S., \& Gielen, S. (2006). On the dynamics of students' approaches to learning: The effects of the teaching/learning environment. Learning and Instruction, 16, 279-294.

Svirko, E., \& Mellanby, J. (2008). Attitudes to e-learning, learning style and achievement in learning neuroanatomy by medical students. Medical Teacher, $30,219-227$

Swanberg, A., \& Martinsen, O. (2010). Personality, approaches to learning and achievement. Educational Psychology, 30(1), 75-88.

Tait, H., \& Entwistle, N. J. (1996). Identifying students at risk through ineffective study strategies. Higher Education, 31(1), 97-116.

Tait, H., Entwistle, N. J., \& McCune, V. (1998). ASSIST: A reconceptualisation of the approaches to studying inventory. In C. Rust (Ed.), Improving student learning: Improving students as learners. Oxford: Oxford Centre for Staff and Learning Development.

Tetik, C., Gurpinar, E., \& Bati, H. (2009). Students' learning approaches at medical schools applying different curricula in Turkey. Kuwait Medical Journal, 41(4), 311-316.

Thomas, C., \& Gadbois, S. (2007). Academic self-handicapping: The role of self-concept clarity and students' learning strategies. British Journal of Educational Psychology, 77, 101-119.

Tiwari, A., Chan, S., Wong, E., Wong, D., Chui, C., Wong, A., et al. (2006). The effect of problem-based learning on students' approaches to learning in the context of clinical nursing education. Nurse Education Today, 26, 430-438.

Trigwell, K., \& Prosser, M. (1991a). Improving the quality of student learning: The influence of learning context and student approaches to learning on learning outcomes. Higher Education, 22, 251-266.

Trigwell, K., \& Prosser, M. (1991b). Relating approaches to study and quality of learning outcomes at the course level. British Journal of Educational Psychology, 61(3), 265-275.

Trigwell, K., Prosser, M., \& Waterhouse, F. (1999). Relations between teachers' approaches to teaching and students' approaches to learning. Higher Education, 37, 57-70.

Tural Dincer, G., \& Akdeniz, A. (2008). Examining learning approaches of science student teachers according to the class level and gender. US-China Education Review, 5(12), 54-59.

Valk, A., \& Marandi, T. (2005). How to support deep learning at a university? In F. E. H. Tay, T. S. Chuan, \& S. Han-Ming (Eds.), Proceedings of the international conference on education 2005. National University of Singapore.

Vanthournout, G., Donche, V., Gijbels, D., \& Van Petegem, P. (2009). Alternative data-analysis techniques in research on student learning: Illustrations of a person-oriented and developmental perspectives. Reflecting Education, 5(2), 35-51.

Waters, L., \& Johnston, C. (2004). Web-delivered, problem-based learning in organisational behaviour: A new form of CAOS. Higher Education Research and Development, 23(4), 413-431.

Watkins, D., \& Regmi, M. (1990). An investigation of the approach to learning of Nepalese tertiary students. Higher Education, 20(4), 459-469.

Wilson, J. (2009). A two factor model of performance approach goals in student motivation for starting medical school. Issues in Educational Research, 19(3), $271-281$.

Wilson, K., \& Fowler, J. (2005). Assessing the impact of learning environments on students' approaches to learning: Comparing conventional and action learning designs. Assessment and Evaluation in Higher Education, 30(1), 87-101.

Wilson, K. L., Lizzio, A., \& Ramsden, P. (1997). The development, validation and appreciation of the Course Experience Questionnaire. Studies in Higher Education, 22, 33-53.

Wilson, K. L., Smart, R. M., \& Watson, R. J. (1996). Gender differences in approaches to learning in first year psychology students. British Journal of Educational Psychology, 66, 59-71.

Wong, D., \& Lam, D. (2007). Problem-based learning in social work: A study of student learning outcomes. Research on Social Work Practice, 17, 55-65.

Yin, L. (1999). A longitudinal study of Hong Kong Chinese university students' academic causal attributions, self-concept, learning approaches, and their causal effects on achievement. Paper presented at the Annual Meeting of the American Educational Research Association, Montreal, Quebec, Canada.

Zeegers, P. (2001). Approaches to learning in science: A longitudinal study. British Journal of Educational Psychology, 71, 115-132.

Zeegers, P. (2002). A revision of the Biggs Study Process Questionnaire (R-SPQ). Higher Education Research and Development, $21,73-92$.

Zeegers, P. (2004). Student learning in higher education: A path analysis of academic achievement in science. Higher Education Research and Development, 23(1), 35-56.

Zhang, L., \& Watkins, D. (2001). Cognitive development and student approaches to learning: An investigation of Perry's theory with Chinese and U.S. university students. Higher Education, 41, 239-261.

Zhang, L. F. (2003). Does the big five predict learning approaches? Personality and Individual Differences, 34(8), 1431-1446. 